\title{
Extrinsic Factors which Influence the Buying Preferences of Residential Real Estate Customers
}

\author{
P. T. Rekha \\ Research Scholar, Bharatamata College, Thrikkakkara, Kerala, India \\ E-Mail: rekhapt77@gmail.com
}

\begin{abstract}
A major effort on the part of Real estate firms is to increase and retain their customers and it is very essential that to know the factors influencing customers' satisfaction and retention. This study is done with the purposes of identifying the extrinsic factors that affect the purchasing decision of the real estate customers of villas and apartments. This study uses survey questionnaires to obtain information from real estate consumers. The study was conducted in Thrissur district. The study found that the most influencing one in extrinsic factors which affect the purchase decision of real estate consumers is the availability of the facility of waste disposal. The study also discuss the opinion of real estate consumers about the changes needed in the structure of flats and villas in the light of natural calamities occurred in Kerala.
\end{abstract}

Keywords: Extrinsic Factors, Buying Preferences, Residential Real Estate Consumers, Thrissur District

\section{INTRODUCTION}

Kerala is one of the smallest states in India. Here people still struggle for the basic needs fulfillment. When still lots of people struggle to have a minimum shelter, real estate products that is assumed to be very expensive, is a kind of extra luxury to the majority of the mass population. However real estate sector in Kerala has been developed and almost in all places of Kerala a huge amount of flats and villas have been formed and the real estate sector is growing with a good pace along with a gradual increase of its contribution in total GDP. Investments in this sector have been increasing over time and completion has becoming sharper because of the increased number of firms as well as stakeholders awareness. Government also trying to build a proper framework for this sector.

Thrissur the Cultural Capital of Kerala, is also considered as a major commercial and business hub of South India. It is said to be the heartland of Kerala's business acumen and home to most every leading entrepreneurs. The city which is famous for Bullion, Banking and its Business acumen, is the darling of investors in Kerala. This city is also referred as the Golden city. It manufactures $70 \%$ of plain gold jewellery in our state per day.

According to a survey, Thrissur has been placed on 7th among the ten cities in our country to reside. According to Registrar of Companies, the period from January 1 to March 31, 2010, 87 companies were registered in this city and stood second in our state. Thrissur's traditional strength lies in best entrepreneurial and financial capabilities. And in this study I am able to discuss with the existing real estate consumers of Thrissur district about the new global concepts that our real estate industry can adopt such as container homes, green roof homes, tiny homes etc.

\section{SIGNIFICANCE OF THE STUDY}

Looking into the residential sector at Thrissur District the customers are with regular and profitable employment, growingly into the purchase of apartments. More over many builders such as Skyline builders, highlife builders, Joy Alukkas Builders, Sobha Developers etc are recently made high investment in this District.The background of this study is to identify the extrinsic factors which highly influence the purchase decision of residential real estate customers of villas and apartments in Thrissur District.

\section{REVIEW OF LITERATURE}

Nasar K K, Dr. Manoj P K, (2014) viewed in their study, 'Factors Influencing the Purchase of Apartments: Some Empirical Evidence', that the developers have to give due regard to the prominent factors that customers expect from the developers in their decision making process that precedes their actual purchase of apartments. Constant interaction of the developers with the respective residents' associations would give them more practical insights on a regular basis that can be used meaningfully in the design and development as well as marketing of their future apartment projects.

Phan Thanh Si (2012) in his study "key factors affecting house Purchase decision of Customers in Vietnam” reveals that there is a strong positive relationship between top two factors, including "living space”, "distance” and customers' housing purchase decision.

Thanakon Ratchatakulpat, Peter Miller, Teresa Marchan (2009), pointed in their article, 'Residential real estate purchase decisions in Australia: is it more than location?', that Buyers may have different views from agents on what constitutes an investment and such buyers want more efficiency and speed in the buying process. Prospective real estate purchasers are concerned with more than property location. Affordability, maintenance and interior design, and a good neighbourhood are considered as most important. Of least importance are the affluence and quality of the area, 
water, views and roads, and features, such as a pool or airconditioning.

\section{OBJECTIVES OF THE STUDY}

1. To identify the extrinsic factors which influence the buying preferences of residential real estate customers of Thrissur district.

2. To discuss the opinion of real estate customers about the changes needed in the structure of flats and villas in the light of natural calamities occurred in Kerala.

\section{METHODOLOGY}

The study covers suitable number of the existing consumers of the villas and apartments in Thrissur District based on convenience sampling method. Sixty samples were collected among the customers of reputed builders in Thrissur District.A total of 65 customers were selected from the customers of reputed builders in Thrissur district. The total 65 number of questionnaires are distributed to respond. Altogether 7 important attributes under extrinsic factor which is incorporated in questionnaire. Out of 65 questionnaires distributed, 60 were retrieved properly (92.31 \%) and 5 numbers of questionnaires (7.69\%) were not responded properly. So they were rejected. Each consumer was asked to respond all the attributes under extrinsic factor on a five-point Likert scale where $1=$ Not Important, 2= Slightly Important, 3 = Moderately Important, 4 = Important, 5= Very important.

\section{SOURCES OF DATA}

Both primary and secondary data was collected for the study.

\section{A. Primary Data}

The primary data was collected from the sample by using structured questionnaire and a survey was conducted among the existing customers of villas and apartments in Thrissur District and a personal interview was done for collecting opinion about the changes needed in the construction of villas and apartments in the light of flood and earthquakes happened in Kerala.

\section{B. Secondary Data}

Various secondary sources like study reports of expert committees, books, journals, periodicals, research articles, news papers, dissertations etc are used for the study.

\section{ANALYSIS AND INTERPRETATIONS}

Among the total respondents 78.33 percent constitute male and 21.67 percent constitute female category.
TABLE I GENDER OF THE RESPONDENTS

\begin{tabular}{|c|c|c|c|c|c|}
\hline & & 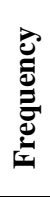 & 芑 & 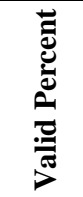 & 胥 \\
\hline \multirow{3}{*}{ Valid } & Male & 47 & 78.3 & 78.3 & 78.3 \\
\hline & Female & 13 & 21.7 & 21.7 & 100.0 \\
\hline & Total & 60 & 100.0 & 100.0 & \\
\hline
\end{tabular}

Among the total respondents 33.3 percent have basic educational qualification and 18.3 percent have professional degree.

TABLE II EDUCATIONAL QUALIFICATIONS

\begin{tabular}{|c|c|c|c|c|c|}
\hline & & 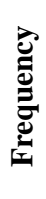 & 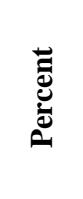 & 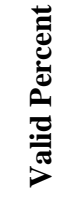 & تِّة \\
\hline \multirow{5}{*}{ Valid } & SSLC/ Plus Two & 20 & 33.3 & 33.3 & 33.3 \\
\hline & Degree & 15 & 25.0 & 25.0 & 58.3 \\
\hline & PG & 14 & 23.3 & 23.3 & 81.7 \\
\hline & Professionals & 11 & 18.3 & 18.3 & 100.0 \\
\hline & Total & 60 & 100.0 & 100.0 & \\
\hline
\end{tabular}

Among the total respondents, 21.7 percent have government jobs or retired from government jobs and the other 21.7 percent belongs to private sector and 15 percent belongs to their own profession and 31.7 percent belongs to business groups and 10 percent belongs to other categories.

TABLE III OCCUPATION OF THE RESPONDENT

\begin{tabular}{|c|c|c|c|c|c|}
\hline & & 㞯 & 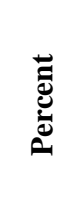 & 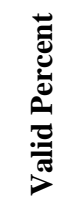 & 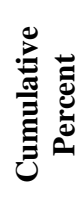 \\
\hline \multirow{6}{*}{ Valid } & Govt/ Govt retired & 13 & 21.7 & 21.7 & 21.7 \\
\hline & Private/ Private retired & 13 & 21.7 & 21.7 & 43.3 \\
\hline & Professionals & 9 & 15.0 & 15.0 & 58.3 \\
\hline & Business & 19 & 31.7 & 31.7 & 90.0 \\
\hline & Others & 6 & 10.0 & 10.0 & 100.0 \\
\hline & Total & 60 & 100.0 & 100.0 & \\
\hline
\end{tabular}

\section{A. Extrinsic Attributes}

Extrinsic attributes means factors which are inside the compound of the building area. Under extrinsic attributes there are seven variables. 
TABLE IV DESCRIPTIVE STATISTICS

\begin{tabular}{|l|c|c|c|c|c|}
\hline & $\mathbf{N}$ & Minimum & Maximum & Mean & Std. Deviation \\
\hline Structure of building & 60 & 2 & 5 & 4.35 & .732 \\
\hline Compound walls & 60 & 1 & 5 & 3.43 & 1.064 \\
\hline Parking & 60 & 2 & 5 & 4.07 & .733 \\
\hline Play area & 60 & 2 & 5 & 4.37 & .758 \\
\hline garden & 60 & 1 & 5 & 3.38 & 1.223 \\
\hline Waste disposal & 60 & 3 & 5 & 4.60 & .588 \\
\hline security & 60 & 1 & 5 & 4.12 & 1.195 \\
\hline Valid N (listwise) & 60 & & & & \\
\hline
\end{tabular}

TABLE V RANKING

\begin{tabular}{|l|c|c|}
\hline \multicolumn{1}{|c|}{ Attributes } & Mean in \% & Rank \\
\hline Structure of building & 87.0 & 3 \\
\hline Compound walls & 81.4 & 5 \\
\hline Parking & 87.4 & 2 \\
\hline Play area & 67.6 & 7 \\
\hline Garden & 68.6 & 6 \\
\hline Waste disposal & 92.0 & 1 \\
\hline Security & 82.4 & 4 \\
\hline
\end{tabular}

\section{LIMITATIONS OF THE STUDY}

The study has been done within Thrissur District only. So that the profile of the study area as well as the basic background of the customers is primarily urban in nature. Thus, the findings reflect the buying behaviour of such a small group.

\section{CONCLUSION AND SUGGESTIONS}

This study has analyzed the most influencing extrinsic factors in the purchase decision of customers of villas and apartments in Thrissur district. The study observed that availability of waste management facility constitute the major influencing one under the extrinsic factors. The overall finding is that customers prefer to purchase those apartments and villas that have effective and efficient waste management facility, that have a good structure or appearance, that have high security, that have individual parking space, that have a compound wall, that have a good space for gardening , that have good play area for children.. The major contribution of this study is that it could provide guidelines to the residential property builders regarding the important factors that need attention along with their corresponding leading factors. Therefore, the study gives some advice to the builders as to how they should design and market their products. And also there are some suggestions that the builders can adopt the concept of tiny homes which allow home buyers to have a house that is space-efficient. Viable for a single or couple dwellers, these homes are just enough for the buyers to live with the minimum. One of the biggest advantages of India adopting this concept is that it can help fulfil the 'Housing for All by 2022 dream'.

\section{REFERENCES}

[1] N. K., \& M. P. (2014, Jul-Dec). Factors influencing the purchase of apartments: Some empirical evidence. CLEAR IJRMST, 04(08), online-ISSN: 2249 -3506 print-ISSN: 2249 -3492. Retrieved August/September, 2018, from http://www.researchgate.net/publica tion/280233069.

[2] Si, P. T. (2012). Key factors affecting house Purchase decision of Customers in Vietnam". MASTER OF BUSINESS (Honours), ID: 60340102. Retrieved from, (2018), (August/September).

[3] T. R., P. M., \& T. M. (2009). Residential real estate purchase decisions in Australia: Is it more than location? International Real Estate Review, 12(3), 237294. (2018, August/September). Retrieved from http://www.umac.mo/fba/irer/.

[4] Makaan.com. (n.d.). (2018, August/September), Retrieved from https://www.makaan.com 